\title{
Addictive Use of Social Media and Motivations for Social Media Use Among Emerging Adult University Students
}

\section{Beliren Yetişkin Üniversite Öğrencileri Arasındaki Sosyal Medya Bağımlılı̆ı̆ ve Sosyal Medya Kullanım Motivasyonları}

\author{
Cebrail Karayiğit ${ }^{1}$ iD, Aubrey Groter ${ }^{1}$ (D), Michael Thompson ${ }^{1}$ (iD
}

1. Pittsburg State University, Department of Psychology \& Counseling, Pittsburg, USA

Abstract

Objective: The purpose of this study was to examine motivations for social media use (social connectedness, entertainment, social recognition, information) and its relationship with the addictive use of social media among emerging adult university students.

Method: In this quantitative study, data were collected from emerging adult university students $(\mathrm{N}=446)$ who completed The Bergen Social Media Addiction Scale (BSMAS) and the Scale of Motives for Using Social Networking Sites (SMU-SNS).

Results: The findings showed a moderately strong, positive relationship between addictive use of social media and social connectedness and social recognition motivations. The findings also revealed that females and on-campus students more frequently experience the addictive use of social media than males and off-campus students.

Conclusion: The findings from this study provided broad support for the notion that there are significant results that it may still be important to explore a further understanding of the link between the addictive use of social media and different motivations for social media use.

Keywords: Addictive use of social media, emerging adult, social connectedness, social recognition

Öz

Amaç: Bu çalışmanın amacı, beliren yetişkin üniversite öğrencileri arasındaki sosyal medya kullanım motivasyonlarını (sosyal bağlılık, eğlence, sosyal tanınma, bilgi) ve bu motivasyonların sosyal medya bağımlılı̆ıyla ile ilişkisini incelemektir.

Yöntem: Nicel araştırma yönteminin kullanıldığı bu çalışmada, veriler Bergen Sosyal Medya Bağımlıık Ölçeği (BSMAS) ve Sosyal Ağ Sitelerini Kullanma Güdüleri Ölçeği'ni (SMU-SNS) tamamlayan beliren yetişkin üniversite öğrencilerden ( $N=446)$ toplanmıştır.

Bulgular: Bulgular sosyal bağlılık ve sosyal tanınma motivasyonlarıyla sosyal medya bağımlılığı arasında orta derecede güçlü ve olumlu bir ilişki olduğunu göstermiştir. Bulgular ayrıca, kadınların ve kampüste yaşayan öğrencilerin daha sık sosyal medya bağımlıı̆ı yaşadıklarını da ortaya koydu.

Sonuç: Bu çalışmadan elde edilen bulgular, sosyal medya bağımlıı̆̆ıyla sosyal medya kullanım motivasyonları arasındaki ilişkinin daha fazla anlaşılmasının önemli olabileceğine dair anlamlı sonuçlar olduğu fikrine geniş destek sağlamıştır.

Anahtar kelimeler: Sosyal medya bağımlılığı, beliren yetişkin, sosyal bağlılık, sosyal tanınma 


\section{Introduction}

Social media use has been on the rise over the last two decades; this is no secret. In the United States, about 9 of 10 young adults (18- to 29-year-olds) use any form of social media $(1,2)$. Many recent studies have found a strong link between social media use and mental health and well-being in emerging adults and college students. For example, previous studies found that frequent use of social media is associated with lower satisfaction in life $(3,4)$ and lower well-being among young adults $(5,6)$. Another study found that routine use of social media was positively associated with well-being and mental health (7).

Higher social media use rates have been linked in various studies to increased anxiety, depression, and substance use. For example, a study conducted by Vannucci et al. showed a positive relationship between social media use and anxiety for emerging adults (8). Another study focusing on young adults found that problematic social media use was associated with a higher rate of depressive symptoms (9). A similar study examined the relationships between emerging adults' psychological functioning and different types of social media and found a strong link between social media use and reported anxiety symptoms as higher levels of reported depressive symptoms, alcohol consumption, and drug use (10). They also found that other than male participants using Twitter more often than their female counterparts did, there were no reported gender differences. A considerable number of studies have focused on the relationship between social media use and certain personality traits $(11,12,13)$. For example, in a recent study examining college students' level of extraversion in relation to social media, Thomas et al. found that highfunctioning introverts were more likely to spend time alone without using social media than extroverts and low-functioning introverts (14). While there has been a growing body of literature on the effects of social media use among emerging adults, research on the relationship between the addictive use of social media $(15,19,20)$ and motivations for social media use is quite scarce. Therefore, the present study aimed to take a closer look at gender differences in social media use motivations, and possible associations between addictive use of social media and motivations for social media use among emerging adult university students.

Findings on the motivations for social media use have varied in recent years. For example, Alhabash and Ma measured college students' use of Facebook, Twitter, Instagram, and Snapchat, and found that entertainment was the most consistent motivation for social media use (21). This study also found that most reported social media use time was spent on Instagram, followed by Snapchat, Facebook, and Twitter. In another study, Lampe et al. found that university students use Facebook as a social search tool to maintain previous relationships (22). In a similar study focusing on college students' social media use, Al-Menayes found that nearly all participants used some form of social media and that their motivations for use fell into the following categories: entertainment, information seeking, personal utility, and convenience (23). Park and Valenzuela found that socializing, entertainment, self-status seeking, and information were the primary motives for participating in Facebook groups for college students (24). A study of gender differences in social media use motivations showed that females tend to use social media for social needs and social connections (25). While Park and Valenzuela found that females were more likely to use social media for obtaining information (24), another study found that males are more likely to use social media for entertainment (26).

Social media addiction has been studied extensively. A considerable number of studies have shown that social media addiction was negatively associated with overall well-being and positively associated with negative outcomes $(27,28,32)$. While frequent use of social media does not necessarily refer to social media addiction, the time spent on social media was positively associated with depressive symptoms (20). Similarly, Balcerowska et al. found that social networking site addiction was positively associated with perceived stress and negatively associated with subjective well-being (27). In line with the above findings, other studies found that social media addiction was negatively related to mental health, academic performance, and self-esteem $(28,29,30,44)$. A study conducted by Andreassen et al. found that being 
female was positively associated with addictive social networking and activities that involve social interaction and cooperation (15).

While these studies focused on the relationship between social media addiction and other factors (e.g., mental health, personality traits), the relationship between the motives for social media use and other variables such as addictive use of social media has been analyzed even less. Thus, this study asks whether emerging adult university students' addictive use of social media is related to different motivations for social media use. We expect that addictive use of social media strongly correlates with social recognition and social connectedness motives. This study also examines how/whether the addictive use of social media and motives for social media use are related to gender and campus residency. We predict that female students more frequently experience the addictive use of social media.

To further examine differences in motivations for social media use and the relations of addictive use of social media with motivations for social media use among emerging adult university students, the present study addresses the following research questions: 1. (a) Are there differences between male and female emerging adult university students in their levels of different social media use motivations (social connectedness, entertainment, social recognition, information) and their levels of addictive use of social media? (b) Are there differences between on-campus and off-campus emerging adult university students in their levels of different social media use motivations (social connectedness, entertainment, social recognition, information) and their levels of addictive use of social media? 2. Among emerging adult university students, is there a relationship between the addictive use of social media and social media use motivations (social connectedness, entertainment, social recognition, information)?

\section{Method}

\section{Sample}

The population for this study was students currently enrolled in a U.S. university. Data was collected from $(\mathrm{N}=446)$ students who were between 18 and 29 years old. Potential participants were recruited using convenience-sampling methods. There were no exclusions for participating in this study except participants must be 18 years of age or over and 29 years of age or under since the study focused on the stage of Emerging Adulthood (33). Of the 446 participants who completed the survey, three participants choose to self-describe their gender. As shown in Table 1, the vast majority of participants identified as female (70.2\%) and off-campus students (70.9\%). While the participants' mean age was 20.5 years (SD $=2.6$, range 18-29), the vast majority of participants (91\%) were between the ages of 18-24.

\section{Procedure}

For this quantitative research, permission was obtained from the Institutional Review Board of the ethics committee of Pittsburg State University, Pittsburg, KS, under the rules for expedited review (dated 08.28.2020, decision number ED21-027).

In this quantitative study, survey design was employed as the main avenue for collecting data from a large number of students at a regional public university in the Midwest of the United States. An electronic version of the survey, including the demographic form, The Bergen Social Media Addiction Scale (BSMAS; 15), and The Scale of Motives for Using Social Networking Sites (SMU-SNS; 31), were used. All responses are measured on a seven-point Likert scale, where $1=$ Strongly Disagree, and $7=$ Strongly Agree.

In the fall of 2020, both undergraduate and graduate students were invited to complete an online survey in return for a chance to win a US\$50 gift certificate. The survey link included a consent form that explained the purpose and significance of the study, the importance of their participation, confidentiality, the anticipated length of the survey, and researcher contact information. Participants were asked to read and agree to the consent form. 


\section{Measures}

Participants rated the six items of the Bergen Social Media Addiction Scale (BSMAS; 15) and 12 items of the Scale of Motives for Using Social Networking Sites (SMU-SNS; 31) on a 7-point Likert scale ranging from 1 (strongly disagree) to 7 (strongly agree). The SMU-SNS scale consist of 27 items, subdivided into seven sub-scales (new friendships, academic purposes, social connectedness, following and monitoring others, entertainment, social recognition, self-expression, and seeking information). For this study, we used only four of seven dimensions of the Scale of Motives for Using Social Networking Sites (social connectedness, entertainment, social recognition, and information) since they were the principal motives for the use of social media in the literature reviewed $(31,34,35,36)$. While social connectedness refers to the motives related to feeling part of society through online social networks, entertainment refers to the motives associated with using social media for fun and passing the time. Another dimension is social recognition, which is related to looking for popularity and feedback (e.g., likes and comments). Lastly, motives related to being aware of news and current social issues refers to the information dimension. Sample items include "to be informed about the news" (Information) and "to feel socially integrated" (Social Connectedness). The Bergen Social Media Addiction Scale (BSMAS; 15), a six-item self-report scale for assessing at-risk social media addiction, represents a modified version of the Bergen Facebook Addiction Scale (BFAS; 17). BSMAS and BFAS can be used interchangeably in the literature $(18,27)$. Sample items include "felt an urge to use social media more and more?"

Internal consistency and reliability were measured using Cronbach's alpha coefficients. Cronbach's alpha indicated that each of the four motives constructs assessed by the SMU-SNS demonstrated acceptable internal consistency (social connectedness, $\alpha=.72$; entertainment, $\alpha=.83$; social recognition, $\alpha=.79$; and information, $\alpha=.75$ ). Results also showed a Cronbach's alpha of $\alpha=0.82$ for the BSMAS, indicating relatively high internal consistency of the items in the scale. While a recent study provided strong support for the validity and reliability of the SMU-SNS, confirmatory factor analysis indicated a well-fitting model for the SMU-SNS (31). The validity of BFAS/BSMAS has been supported across different studies $(16,17,27,37,38)$.

\section{Statistical Analysis}

SPSS software (version 24) was used to analyze the data. Frequencies, Pearson Correlations, and an independent-samples t-test were utilized. First, an independent t-test was conducted to assess if the level of different social media use motivations (social connectedness, entertainment, social recognition, information) and the level of addictive use of social media differ between female and male emerging adult university students. Another independent t-test was used to determine whether there was a significant difference in social media use motivations (social connectedness, entertainment, social recognition, information) and addictive use of social media between on-campus and off-campus emerging adult university students. Lastly, to examine research question two, a correlation analysis was used to determine a possible relationship between different social media use motivations (social connectedness, entertainment, social recognition, information) and addictive use of social media among emerging adult university students.

\section{Results}

The scores from four social media use motivations sub-scales and addiction scale were used to address the first research question. An independent t-test was used to determine whether there was a statistically mean difference in the levels of different social media use motivations (social connectedness, entertainment, social recognition, and information) and the level of addictive use of social media differ between female and male emerging adult university students. As shown in table 2, female emerging adult students $(M=3.44, S D=1.14$ ) were significantly higher in their mean level of addictive use of social media than male emerging adult university students $(M=2.58, S D=1.10), t(441)=-7.30, p=0.00$. Female emerging adult students were also significantly higher in their mean of social connectedness, 
entertainment, and social recognition than male emerging adult university students, $(M=5.00, S D=$ 1.10), $\mathrm{t}(441)=-5.94, \mathrm{p}=0.00 ;(\mathrm{M}=5.99, \mathrm{SD}=0.84), \mathrm{t}(441)=-3.77, \mathrm{p}=0.00 ;(\mathrm{M}=2.85, \mathrm{SD}=$ 1.30), $\mathrm{t}(441)=-5.15, p=0.00$. However, there was no significant differences between female and male emerging adult university students on levels of information motive, $t(441)=-0.25, p=0.79$. Further, the effect sizes for social recognition, social connectedness, and addiction were at $d=.54, d=.58, d=.77$, which is considered a medium to large effect size using Cohen's criteria (39). While the effect size (Cohen's d) for information sub-scale were low at $d=.02$ respectively, and the effect size for entertainment sub-scale were at $d=.37$, which is considered a low to medium effect size.

Table 1. Demographic data of the study population

\begin{tabular}{|c|c|c|}
\hline Variable & Frequenc & Percent \\
\hline \multicolumn{3}{|l|}{ Age } \\
\hline $18-24$ & 406 & 91.0 \\
\hline $25-29$ & 40 & 9.0 \\
\hline \multicolumn{3}{|c|}{ Campus Residency } \\
\hline On-campus & 130 & 29.1 \\
\hline Off-campus & 316 & 70.9 \\
\hline \multicolumn{3}{|l|}{ Gender } \\
\hline Female & 313 & 70.2 \\
\hline Male & 130 & 29.1 \\
\hline Total & 446 & 100 \\
\hline
\end{tabular}

Table 2. Social media motives and addiction by gender

\begin{tabular}{|l|l|c|c|c|c|c|c|c|}
\hline & Student Status & N & M & SD & SEM & t & df & p \\
\hline S-Connectedness & Female & 313 & 5.00 & 1.10 & 0.06 & -5.94 & 441 & 0.00 \\
\hline & Male & 130 & 4.24 & 1.49 & 0.13 & & & \\
\hline Entertainment & Female & 313 & 5.99 & 0.84 & 0.04 & -3.77 & 441 & 0.00 \\
\hline & Male & 130 & 5.62 & 1.12 & 0.09 & & & \\
\hline S-Recognition & Female & 313 & 2.85 & 1.30 & 0.07 & -5.15 & 441 & 0.00 \\
\hline & Male & 130 & 2.17 & 1.19 & 0.10 & & & \\
\hline Information & Female & 313 & 5.29 & 1.12 & 0.06 & -0.25 & 441 & 0.79 \\
\hline & Male & 130 & 5.26 & 1.28 & 0.11 & & & \\
\hline Addiction & Female & 313 & 3.44 & 1.14 & 0.06 & -7.30 & 441 & 0.00 \\
\hline & Male & 130 & 2.58 & 1.10 & 0.09 & & & \\
\hline
\end{tabular}

S-Connectedness $=$ Social Connectedness, S-Recognition $=$ Social Recognition

Another independent t-test was conducted to assess if the level of each of the four social media use motivations (social connectedness, entertainment, social recognition, and information) and the level of addictive use of social media differed between on-campuss and off-campus emerging adult university students. The result of the analysis showed that on-campus students $(M=3.49, S D=1.27)$ had significantly higher mean scores than off-campus students $(M=3.08, S D=1.15)$ in addictive use of social media, $t(444)=3.32, p=0.00$. As shown in table 3 , on-campus emerging adult students $(M=$ $5.01, S D=1.17$ ) were also significantly higher in their mean level of social connectedness motive than off-campus students $(M=4.69, S D=1.31), t(444)=2.38, p=0.01$. On the other hand, while social recognition and information mean values resulted higher in on-campus students (respectively, $M=$ 2.82, $S D=1.32$ and $M=5.43, S D=0.99$ ) than in off-campus students (respectively, $M=2.58, S D=$ 1.29 and $M=5.23, S D=1.23$ ) without reaching a statistical significance $(p=0.09$ and $p=0.10)$, oncampus and off-campus students did not significantly differ on levels of entertainment $t(444)=1.62, p=$ 0.37 . While the effect sizes for social connectedness and addiction were at $d=.25$ and $d=.33$, which is considered a small to medium effect size using Cohen's criteria, the effect sizes (Cohen's $d$ ) for 
entertainment, social recognition, and information sub-scales were all low at $d=.08, d=.18$, and $d=$ .17 respectively.

Table 3. Social media motives and addiction by campus residency

\begin{tabular}{|l|l|l|l|l|l|l|l|l|}
\hline & Campus Residency & N & M & SD & SEM & t & df & p \\
\hline S-Connectedness & On-campus & 130 & 5.01 & 1.17 & 0.10 & 2.38 & 444 & 0.01 \\
\hline & Off-campus & 316 & 4.69 & 1.31 & 0.07 & & & \\
\hline Entertainment & On-campus & 130 & 5.94 & 0.99 & 0.08 & 0.89 & 444 & 0.37 \\
\hline & Off-campus & 316 & 5.86 & 0.92 & 0.05 & & & \\
\hline S-Recognition & On-campus & 130 & 2.82 & 1.32 & 0.11 & 1.69 & 444 & 0.09 \\
\hline & Off-campus & 316 & 2.58 & 1.29 & 0.07 & & & \\
\hline Information & On-campus & 130 & 5.43 & 0.99 & 0.08 & 1.62 & 444 & 0.10 \\
\hline & Off-campus & 316 & 5.23 & 1.23 & 0.06 & & & \\
\hline Addiction & On-campus & 130 & 3.49 & 1.27 & 0.11 & 3.32 & 444 & 0.00 \\
\hline & Off-campus & 316 & 3.08 & 1.15 & 0.06 & & & \\
\hline
\end{tabular}

S-Connectedness $=$ Social Connectedness, S-Recognition $=$ Social Recognition

The scores from all four subscales (social connectedness, entertainment, social recognition, and comfort with differences) and the addiction scale were used to address the second research question. Cohen's criteria (a correlation coefficient of .10 represents a weak or small association; .30 is considered a moderate correlation; .50 or larger represents a strong or large correlation) were used to interpret effects sizes and estimate the degree of linear relationship between two variables (39). As shown in Table 4, there was a moderate positive relationship between addictive use of social media and social connectedness, $r(446)=.470, p=.00$, and a positive relationship between addictive use of social media and social recognition, $r(446)=.442, p=.00$. In other words, increases in social connectedness and social recognition motivations were moderately correlated with increases in the addictive use of social media. The results of correlation analysis (two-tailed) also showed that there was a weak positive relationship between the addictive use of social media and entertainment motive, $r(446)=.288, p=.00$, and a weak positive relationship between the addictive use of social media and information motive, $r(446)$ $=.163, p=.01$.

Table 4. Pearson correlation between addictive use of social media and social media use motivations

\begin{tabular}{|l|l|c|}
\hline Variable & & \\
\hline Social Connectedness & Pearson Correlation & $.470^{\star}$ \\
\hline & Sig. (2-tailed) & .00 \\
\hline & $\mathrm{N}$ & 446 \\
\hline Entertainment & Pearson Correlation & $.288^{\star}$ \\
\hline & Sig. (2-tailed) & .00 \\
\hline & $\mathrm{N}$ & 446 \\
\hline Social Recognition & Pearson Correlation & $.442^{\star}$ \\
\hline & Sig. (2-tailed) & .00 \\
\hline Information & $\mathrm{N}$ & 446 \\
\hline & Pearson Correlation & $.163^{\star}$ \\
\hline & Sig. (2-tailed) & .01 \\
\hline & $\mathrm{N}$ & 446 \\
\hline
\end{tabular}

${ }^{*}$ Correlation is significant at the 0.01 level (2-tailed).

\section{Discussion}

This study focused on the motivations for social media use (namely social connectedness, entertainment, social recognition, and information) and their relationship with the addictive use of social media among 
emerging adult university students. Emphasis was placed on the differences between specific groups of emerging adult university students (e.g., male and female students, on-campus and off-campus students). The current findings suggest that female students more frequently experience the addictive use of social media. This finding is consistent with a past study that showed being female was positively associated with the addictive use of social media (15). According to Andreassen et al., this might be explained as "female proneness toward activities that involve social interaction and cooperation" (15).

While the current study found that female emerging adult students had significantly higher mean levels on social connectedness and social recognition, the notion that female students are more likely to use social media for seeking information $(24,40,41)$ were not supported. Our finding on females having significantly higher mean levels on social connectedness and social recognition is consistent with Joinson's study (43) documenting females scoring higher on social connection and Krasnova et al. (25) stating that women tend to use social media for social needs. The current study also found that female emerging adult students had significantly higher mean levels on entertainment, which contradicts with Follows's study reporting that males are more likely to use social media for entertainment (26). While Krasnova et al.'s study showed that men tend to use social media for seeking information (25); however, the current study did not find any significant differences between males and females on the use of social media for information.

The current research study was the first of its kind to examine if on-campus and off-campus students differ on their levels of motivations for social media use and level of addictive use of social media. It was expected that on-campus residency being strongly associated with the addictive use of social media. The hypothesis was based on the assumption that on-campus students might use social media more frequently because of reliable internet access in on-campus housing and the need to connect with their Campus community (42). The findings of the present study supported this assumption. On-campus students had a significantly higher mean of the addictive use of social media and social connectedness motive than off-campus students did. However, previous studies have not fully addressed differences between on-campus and off-campus students on their social media use motivations. Therefore, it is unclear whether differences in social media use motivations are due to residency status or other factors.

This study also examined whether emerging adult university students' level of the addictive use of social media has a relationship with motivations for social media use (social connectedness, entertainment, social recognition, information). The results suggested that the addictive use of social media was positively related to both social connectedness and social recognition motivations. The present findings might suggest that emerging adult university students find it difficult to engage socially; thus, using social media more frequently. In other words, social isolation during Covid-19 might explain why emerging adults' social needs (social connectedness and social recognition) were significantly related to addictive use of social media. The findings from this study have provided insights into the motivations for social media use in relation to addictive use of social media among emerging adult university students. The presence of a few statistically significant results also suggests motivations for social media use vary based on their gender and campus residency, which provides a preliminary basis for future research in this area.

The purpose of this study was to investigate motivations for social media use in emerging adult university students, particularly in relation to addictive use of social media. While the present study represents a starting point in this promising line of inquiry, the findings generally support the notion that female and oncampus students more frequently experience the addictive use of social media. This study also showed that the link between the addictive use of social media and social connectedness and social recognition motives needs more attention. In conclusion, the findings from this study provided broad support for the notion that there are significant results that it may still be important to explore a further understanding of the link between the addictive use of social media and different motivations for social media use.

The present study has some limitations. The external validity of this study might be questionable since participants were recruited from a rural, mid-sized public institution. Therefore, future studies should include more diverse and larger samples. Another significant potential limitation concerns the study's 
selection of analysis because significant relationships do not refer cause and effect, but merely association. Lastly, another major limitation of this study was having relatively small sample sizes for specific groups (e.g., male participants), which might negatively affect researcher's ability to generalize. In order to be able to generalize the findings to emerging adults, such limitations related to sampling should be addressed in future research studies. Future research might also focus on understanding if different factors (e.g., depression, social isolation during Covid-19) can trigger motivations for social media use and the addictive use of social media instead of focusing on gender and campus residency.

\section{References}

1. Perrin A, Anderson M. Social Media Use in the U.S. Washington DC: Pew Research Center, 2019.

2. Perrin A, Anderson M. Share of U.S. adults using social media, including Facebook, is mostly unchanged since 2018. Pew Research center: Fact Tank, 10.04.2019.

3. Smith A, Anderson M. Social Media Use in 2018. Washington DC: Pew Research Center, 2018.

4. Stieger S. Facebook usage and life satisfaction. Front Psychol 2019; 10: 2711.

5. Tromholt M. The facebook experiment: quitting facebook leads to higher levels of well-being. Cyberpsychol Behav Social Netw 2016; 19: 661-666.

6. Kross E, Verduyn P, Demiralp E, et al. Facebook use predicts declines in subjective well-being in young adults. PloS One 2013; 8(8): e69841.

7. Primack BA, Shensa A, Escobar-Viera CG, et al. Use of multiple social media platforms and symptoms of depression and anxiety: A nationally-representative study among U.S. young adults. Comput Hum Behav 2017; 69: 1-9.

8. Bekalu MA, McCloud RF, Viswanath K. Association of social media use with social well-being, positive mental health, and self-rated health: Disentangling routine use from emotional connection to use. Health Educ Behav 2019; 46(Suppl 2): 69-80.

9. Vannucci A, Flannery KM, Ohannessian CM. Social media use and anxiety in emerging adults. J Affect Disord 2017; 207: 163-166.

10. Shensa A, Escobar-Viera CG, Sidani JE, et al. Problematic social media use and depressive symptoms among U.S. young adults: A nationally-representative study. Soc Sci Med 2017; 182: 150-157.

11. Vannucci A, Ohannessian CM, Gagnon S. Use of multiple social media platforms in relation to psychological functioning in emerging adults. Emerg Adulthood 2019; 7(6): 501-506.

12. Amichai-Hamburger Y, Vinitzky G. Social network use and personality. Comput Human Behav. 2010; 26(6): 1289-1295.

13. Caci B, Cardaci M, Miceli S. Development and maintenance of self-disclosure on facebook: the role of personality traits. SAGE Open 2019; 9(2): doi:10.1177/2158244019856948.

14. Jackson LA, Wang JL. Cultural differences in social networking site use: A comparative study of China and the United States. Comput Hum Behav 2013; 29(3): 910-921.

15. Thomas V, Balzer CB, Azmitia M, Whittaker S. Alone and online: Understanding the relationships between social media, solitude, and psychological adjustment. Psychol. Pop. Media 2020; doi: 10.1037/ppm0000287.

16. Andreassen CS, Billieux J, Griffiths MD, et al. The relationship between addictive use of social media and video games and symptoms of psychiatric disorders: A large-scale cross-sectional study. Psychol Addict Behav 2016; 30(2): 252-262.

17. Andreassen CS, Griffiths MD, Gjertsen SR, et al. The relationships between behavioral addictions and the fivefactor model of personality. J Behav Addict. 2013; 2: 90-99.

18. Andreassen CS, Torsheim T, Brunborg GS, Pallesen S. Development of a Facebook Addiction Scale. Psychol Rep 2012; 110: 501-517.

19. Andreassen CS, Pallesen S, Griffiths MD. The relationship between addictive use of social media, narcissism, and self-esteem: Findings from a large national survey. Addict Behav 2017; 64: 287-293.

20. Kuss DJ, Griffiths MD. Social networking sites and addiction: ten lessons learned. Int J Environ Res Public Health. 2017; 14(3): 311.

21. Ryan T, Chester A, Reece J, Xenos S. The uses and abuses of Facebook: A review of Facebook addiction. J Behav Addict. 2014; 3(3): 133-148.

22. Alhabash S, Ma M. A tale of four platforms: motivations and uses of Facebook, Twitter, Instagram, and Snapchat among college students? Soc Media Soc 2017; 3(1): doi: 10.1177/2056305117691544. 
23. Lampe C, Ellison N, Steinfield C. Changes in Use and Perception of Facebook. Proceedings of the ACM Conference on Comput Support Coop Work (CSCW) 2008; 721-730.

24. Al-Menayes J. Motivations for using social media: An exploratory factor analysis. Int J Psychol Res 2015; 7(1): 43-50.

25. Park NK, Valenzuela KS. Being immersed in social networking environment: Facebook groups, uses and gratifications, and social outcomes. Cyberpsychol Behav 2009; 12(6): 729-733.

26. Krasnova $\mathrm{H}$, Veltri NF, Eling $\mathrm{N}$, Buxmann $\mathrm{P}$. Why men and women continue to use social networking sites: The role of gender differences. J Strateg Inf Syst. 2017; 26: 261-284.

27. Follows D. How Women and Men Use the Internet. Washington DC: Pew Research Center, 2005 (December 28).

28. Balcerowska JM, Bereznowski $P$, Biernatowska $A$, et al. Is it meaningful to distinguish between Facebook addiction and social networking sites addiction? Psychometric analysis of Facebook addiction and social networking sites addiction scales. Curr Psychol. 2020; doi: 10.1007/s12144-020-00625-3.

29. Hou Y, Xiong D, Jiang T, et al. Social media addiction: Its impact, mediation, and intervention. Cyberpsychology (Brno) 2019; 13(1): Article 4.

30. Pantic I, Damjanovic A, Todorovic J, et al. Association between online social networking and depression in high school students: Behavioral physiology viewpoint. Psychiatr Danub. 2012; 24: 90-93.

31. Jelenchick LA, Eickhoff JC, Moreno MA. "Facebook depression?" Social networking site use and depression in older adolescents. J Adolesc Health 2013; 52: 128-130.

32. Pertegal MÁ, Oliva A, Rodríguez-Meirinhos A. Development and validation of the Scale of Motives for Using Social Networking Sites (SMU-SNS) for adolescents and youths. PloS One 2019; 14(12): e0225781.

33. Lin LY, Sidani JE, Shensa A, et al. Association between social media use and depression among US young adults. Depress Anxiety 2016; 33: 323-331.

34. Arnett JJ, Žukauskienè R, Sugimura K. The new life stage of emerging adulthood at ages 18-29 years: Implications for mental health. Lancet Psychiatry 2014; 1(7): 569-576.

35. Aladwani AM. Gravitating towards Facebook (GoToFB): What it is? and How can it be measured? Comput Hum Behav 2014; 33: 270-278.

36. Cheung CMK, Chiu PY, Lee MKO. Online social networks: Why do students use Facebook? Comput Hum Behav 2011; 27(4): 1337-1343.

37. Sheldon P. Student favorite: Facebook \& motives for its use. South Commun J 2008; 23: 39-55.

38. Phanasathit M., Manwong M., Hanprathet N, et al. Validation of the Thai version of Bergen Facebook Addiction Scale (Thai-BFAS). J Med Assoc Thai 2015; 98(2):108-117.

39. Wang CW, Ho RTH, Chan CLW, Tse S. Exploring personality characteristics of Chinese adolescents with internet-related addictive behaviors: Trait differences for gaming addiction and social networking addiction. Addict Behav 2015; 42: 32-35.

40. Cohen J. Statistical Power Analysis for the Behavioral Sciences (2nd ed.) 1988. Hillsdale, NJ: Lawrence Earlbaum Associates.

41. Noguti V, Singh S. Waller DS. Gender differences in motivations to use social networking sites. In Management Association, I. (Ed.), Social Media Marketing: Breakthroughs in Research and Practice 1988; 680-695. IGI Global.

42. Noguti V. Post language and user engagement in online content communities. Eur J Mark 2016; 50(5/6): 695723.

43. Allen J, Robbins SB, Casillas A, Oh IS. Third-year college retention and transfer: effects of academic performance, motivation, and social connectedness. Res High Educ 2008; 49(7): 647-664.

44. Joinson AN. 'Looking at', 'looking up' or 'keeping up with' people? Motives and uses of Facebook. In Con Hum Factor Comput Syst 2008; 1027-1036.

45. Błachnio A, Przepiorka A, Pantic I. Association between Facebook addiction, self-esteem and life satisfaction: A cross-sectional study. Comput Hum Behav 2016; 55: 701-705. 